\title{
Tinnitus handicap inventory: adaptação cultural para o Português Brasileiro******
}

\section{Tinnitus handicap inventory: cross-cultural adaptation to Brazilian Portuguese}

\author{
Paula Érika Alves Ferreira* (e-mail: paulaerika@ig.com.br) \\ Fabiana Cunha** \\ Ektor Tsuneo Onishi*** \\ Fátima Cristina Alves Branco-Barreiro**** \\ Fernando Freitas Ganança*****
}

*Fonoaudióloga. Especialista em Audiologia Educacional pela Irmandade de Misericórdia da Santa Casa de São Paulo.

Fonoaudióloga Observadora Voluntária do Setor de Reabilitação Vestibular da Disciplina de Otoneurologia da Universidade Federal de São Paulo (Unifesp).

**Fonoaudióloga. Mestre em Ciências pelo Programa de Pós-Graduação em Otorrinolaringologia e Cirurgia de Cabeça e Pescoço da Unifesp - Escola Paulista de Medicina (EPM)

***Médico. Doutor em Medicina pelo Departamento de Otorrinolaringologia e Departamento de Cirurgia de Cabeça e Pescoço da Unifesp - EPM.

****Fonoaudióloga. Doutora em Psicologia pela Universidade de São Paulo (USP). Professora Assistente e Mestre em Neurociências pelo Instituto de Psicologia da USP.

*****Médico. Doutor em Medicina pela Unifesp. Professor Afiliado da Disciplina de Otoneurologia e Cirurgia de Cabeça e Pescoço da Unifesp - EPM.

\section{******Trabalho Realizado na Unifesp} - EPM.

Artigo de Pesquisa

Artigo Submetido a Avaliação por Pares

Conflito de Interesse: não

Recebido em 5.10.2004.

Revisado em 2.12.2004; 1.06.2005; 20.09.2005.

Aceito para Publicação em 20.09.2005.

\begin{abstract}
Background: tinnitus can cause damage to the life quality of patients. The assessment of to what extent a patient's quality of life has been affected by tinnitus can be useful to understand the limitations imposed by this symptom. Also it can be useful for therapeutic programming and for the verification of therapy effectiveness (pre and post treatment evaluation). Aim: to culturally adapt the Tinnitus Handicap Inventory (THI), to use it with the Brazilian population and to evaluate its reproducibility. Method: the cultural adaptation of the THI (Newman et al., 1996) followed the steps indicated by Guillemin et al., (1993), which include the translation from English to Portuguese, linguistic adaptation and revision of the grammatical and idiomatic equivalences. Assessment of inter and intra-researcher reproducibility of results was also made. Participants of this study were thirty patients (19 females, $63,3 \%$ and 11 males, $36,7 \%$ ) with tinnitus from an otoneurology specialized ambulatory, with ages between 39 and 79 years. Results: the THI was adapted in order to be used with the Brazilian population and was named Brazilian Tinnitus Handicap Inventory. There was no statistically significant difference regarding inter and intra-researcher reproducibility of the results when using the Brazilian version of the questionnaire. A decline in the quality of life regarding emotional, functional and/or catastrophic aspects was observed for all of the assessed patients. Conclusion: the THI was translated and culturally adapted in order to be used with the Brazilian population, demonstrating to be a reliable instrument to verify the damage caused by tinnitus in the quality of life of individuals.
\end{abstract}

Key Words: Tinnitus; Quality of Life; Questionnaires; Disability Evaluation; Reproducibility of Results.

\section{Resumo}

Tema: o zumbido pode provocar muitos prejuízos na qualidade de vida dos pacientes. A avaliação de quanto a qualidade de vida é prejudicada pelo zumbido pode ser útil para o melhor conhecimento do paciente em relação às limitações impostas por este sintoma, a programação terapêutica e a verificação da eficácia terapêutica, quando aplicado antes e após o tratamento. Objetivo: adaptar culturalmente o Tinnitus Handicap Inventory (THI) para aplicação na população brasileira e avaliar a sua reprodutibilidade. Método: a adaptação cultural do THI (Newman et al., 1996) seguiu as etapas indicadas por Guillemin et al. (1993), que incluem a tradução do idioma Inglês para o Português, adaptação lingüística e revisão das equivalências gramatical e idiomática. Realizou-se, também, a avaliação das reprodutibilidades inter e intra-pesquisadores deste questionário. Participaram 30 pacientes com zumbido, dos sexos feminino 19 $(63,3 \%)$ ou masculino 11 (36,7\%), com idade entre 39 e 79 anos (média 56,8 anos), encaminhados a partir de ambulatório específico em otoneurologia. Resultados: o THI foi adaptado para ser aplicado na população brasileira, denominado THI Brasileiro. Não houve diferença estatisticamente significante quanto à reprodutibilidade inter-pesquisadores nos resultados obtidos à aplicação da versão brasileira deste questionário, bem como da reprodutibilidade intra-pesquisadores. Verificou-se prejuízo da qualidade de vida em relação aos aspectos emocionais, funcionais e/ou catastróficos em todos os pacientes avaliados. Conclusão: o THI foi traduzido e adaptado culturalmente para ser aplicado na população brasileira, mostrando-se um instrumento confiável para verificação do prejuízo causado pelo zumbido na qualidade de vida.

Palavras-Chave: Zumbido; Qualidade de Vida; Questionários; Avaliação da Deficiência; Reprodutibilidade de Resultados. 


\section{Introduction}

The tinnitus is one of the three most important otoneurological manifestations besides the sensorineural hearing loss and the vertigo. This symptom may be defined as a sound sensation realized by the individual, independently of an external sound source (Fukuda, 1998).

According to Castagno and Castagno (1985), the tinnitus has a high prevalence, being present in $63,3 \%$ of the individuals over 45 years of age. Concerning the injuries caused by this symptom, it can be observed reasoning, memory and concentration failures. These disorders may hind pleasurable activities, resting, communication, social and domestic environment, interfering on the psychic sphere provoking irritation, anxiety, depression and insomnia. Approximately 17\% of the population is affected by tinnitus, of which 15 to $25 \%$ present interference on their Quality of Life (QL) (Bento et al., 1997).

The tinnitus severity may lead to aggravation effects on the QL of patients (Coles at al., 1981). It may be accompanied by unpleasant symptoms, such as intolerance to loud sounds that may cause important emotional disorders (Casaprima, 2001).

Despite the controversies regarding the most appropriate concept of Quality of Life, the impact of diseases and their repercussions is an issue of raising concern, that aims at a better understanding and assistance by the professionals (Bender, 1996; Fielder et al., 1996; Nascimento, 1999).

Although the otoneurological exams, such as pure tone audiometry, electronystagmography and electrocochleography facilitate the clinical diagnosis confirmation and the treatment option, they are not specifically sensitive or specific to demonstrate the damages caused by the tinnitus in the QL.

Several specialties use instruments to evaluate the $\mathrm{QL}$ in the clinical routine and in the treatment monitoring (Ciconelli, 1993; Castro, 2003).

Most of the instruments that evaluate the QL were developed in English and were intended to be used in English speaking countries. There is a need to develop instruments to be used in countries where English is not spoken or with immigrant populations. Therefore, a new instrument may be developed or an existing one may be translated into another language (Guillemin et al., 1993).

There are two types of questionnaires that may be used: the specific ones for certain diseases or body parts, that are prefered by the clinicians; and the generic ones that evaluate the general health status of the person (Fielder et al., 1996). Some questionnaires to evaluate the QL are already being used in Portuguese; however none of them specifically focus on the tinnitus.

Newman at al. (1996) developed a specific questionnaire named Tinnitus Handicap Inventory (THI) that evaluates the emotional, functional and catastrophic aspects, and is of easy application and interpretation. Baguley et al. (2000) and Berry et al. (2002) used the THI in order to quantify the clinical improvement of the tinnitus and they stressed its usefulness in monitoring and evaluating the proposed treatment.

The THI has been culturally adapted in order to be applied in the Danish population by Zachariae at al. (2000) and in the Spanish population by Norman and Baguley (2001).

The aims of this research were: 1 . to culturally adapt the Tinnitus Handicap Inventory (THI) for its application in the Brazilian population; 2. to evaluate the reproductibility of the THI; 3 . to describe the results of this questionnaire application in patients with tinnitus.

\section{Method}

This research was approved by the Research Ethics Committee of the Federal University of São Paulo (UNIFESP-EPM), under the protocol number $0371 / 04$. Thirty patients with tinnitus, both male and female, signed the Informed Consent Term, and were referred by the OtoNeurology and by the Tinnitus Ambulatories of the same institution.

The translation and cultural adaptation of the THI questionnaire elaborated by Newman at al. (1996) followed the stages proposed by Guillemin et al. (1993), including: the translation from English to Portuguese and the linguistic adaptation; the review of the grammatical and idiomatic equivalence; and the cultural adaptation. Furthermore, the inter and intraexaminer reproductibility was evaluated.

This questionnaire contains 25 numbered questions. Questions number 03, 06, 10, 14, 16, 17, 21, 22 and 25 evaluate the emotional aspect. Questions number 01, 02, 04, 07, 09, 12, 13, 15, 18, 20 and 24 evaluate the functional aspect and questions number 05, 08, 11, 19 and 23 evaluate the catastrophic aspect (CHART 1). 
CHART 1. Tinnitus Handicap Inventory (Newmam et al., 1996).

1. Because of your tinnitus is it difficult for you to concentrate?

2. Does the loudness of your tinnitus make it difficult for you to hear people?

3. Does your tinnitus make you angry?

4. Does your tinnitus make you feel confused?

5. Because of your tinnitus, do you feel desperate?

6. Do you complain a great deal about your tinnitus?

7. Because of your tinnitus do you have trouble falling to sleep at night?

8. Do you feel as though you cannot escape your tinnitus?

9. Does your tinnitus interfere with your ability to enjoy social activities (such as going out to dinner, to the movies)?

10. Because of you tinnitus do you feel frustrated?

11. Because of your tinnitus do you feel that you have a terrible disease?

12. Does your tinnitus make it difficult for you to enjoy life?

13. Does your tinnitus interfere with your job or household responsibilities?

14. Because of your tinnitus do you find that you are often irritable?

15. Because of your tinnitus is it difficult for you to read?

16. Does your tinnitus make you upset?

17. Do you feel that your tinnitus problem has placed stress on your relationship with members of your family and friends?

18. Do you find it difficult to focus your attention away from your tinnitus and on other things?

19. Do you feel that you have no control over your tinnitus?

20. Because of your tinnitus do you often feel tired?

21. Because of your tinnitus do you feel depressed?

22. Does your tinnitus make you feel anxious?

23. Do you feel that you can no longer cope with your tinnitus?

24. Does your tinnitus get worse when you are under stress?

25 . Does your tinnitus make you feel insecure?

Translation from English to Portuguese and linguistic adaptation

The questionnaire was handed to three fluent English teachers translators who did not know each other and did not previously know the questionnaire, in order for them to individually and secretly elaborate the first Portuguese version. This procedure was done aiming at the elaboration of three independent translations of the THI.

The reviser group was composed by a doctor and two speech and hearing pathologists (Brazilian and fluent knower of English) who analyzed all three documents and, by consensus, reduced the differences found in the translations, choosing the best expressions and words for all questions, adapting the text to the Brazilian cultural knowledge. This stage consisted of choosing the best translation for the questions and of modifying by approximation of the most appropriate terms, in order to allow their understanding by the Brazilian population.

This way, a new and unique questionnaire named Brazilian Tinnitus Handicap Inventory or Brazilian THI was obtained.
Grammatical and idiomatic equivalence review

Subsequently, a copy of the Brazilian THI was sent to three different translators of same linguistic and cultural conditions as the first ones. These translators did not know the original text and backtranslated the questionnaire to English. It was not allowed for these new translators to get in touch with the original English text, in order to avoid any possible influence. The same reviser group evaluated the three resulting versions and compared them to the original English version.

\section{Cultural adaptation}

The cultural adaptation of the Brazilian THI aimed at establishing a cultural equivalence between the English and the Portuguese versions of the questionnaire.

According to Guillemin et al. (1993), the cultural equivalence is established when there is no understanding difficulty of the questions or terms by the population; when at least $80 \%$ of the individuals do not show any type of answering difficulty. If this number is beyond the established limit, this question is individually submitted to a new process of translation and back-translation.

A first interviewer (INTERVIEWER 1) applied the questionnaire, reading orally each question in order to include the patients with visual disorder and those illiterate. Thirty patients with tinnitus were interviewed individually. The possible answers for the questions were "yes", "no" and "sometimes". The "yes" answers received score 04, the "no" answers received score zero (00) and the "sometimes" answers received score 02 . The questions that weren't clear for the patients were selected for posterior analysis.

The total score as well as each aspect's score (functional, emotional and catastrophic) were calculated. This way, the highest possible score corresponds to 100 and reveals a maximum change of QL caused by the tinnitus; the lowest possible score corresponds to zero and does not show damage to the QL. Therefore, the total score for each aspect analyzed was: 36 for the emotional aspect, 44 for the functional aspect and 20 for the catastrophic aspect.

Reproductibility of the questionnaire

To test the interexaminer reproductibility, the questionnaire was applied with the same 30 patients by a second researcher (INTERVIEWER 
2). In the same day of the interview the questionnaire was applied again by the first interviewer (INTERVIEWER 1) in order to evaluate the intraexaminer reproductibility.

\section{Statistical Method}

The Analysis of Variance (ANOVA) according to Murray (1993) was used, which is a parametric technique that aims at comparing the averages using a variance in order to evaluate the difference inter and intraexaminer as regards to the resulting scores obtained with the Brazilian THI application. Furthermore, it was also used a technique named Confidence Interval (Fonseca and Martins, 1996) with a significance level (á) of 0,05 (5\%).

\section{Results}

In this research 30 patients with tinnitus took part in the translation and cultural adaptation process of the THI. Of those, $19(63,3 \%)$ were female and $11(36,7 \%)$ were male, ranging in age from 39 to 79 years (mean age $=56,8$ years).

The Brazilian THI obtained from the translation from English to Portuguese and from the linguistic adaptation, is found in CHART 2.

The English version obtained from the backtranslation of the Brazilian THI by the three last teachers was compared to the original version of the THI (Newman et al., 1996) and the grammatical and idiomatic equivalence was established between the two versions.

In the cultural adaptation stage, the Brazilian THI was individually applied in the patients, being well understood by the individuals. It wasn't necessary to review any of its questions. Understanding problems were not observed, since the minimum level of $20 \%$ for a question to be reformulated was reached.

The results obtained with the application of the Brazilian THI by INTERVIEWER 2 are found in TABLE 1.

Concerning the interexaminer reproductibility, no statistical difference was found between the results obtained with the application of the Brazilian THI by INTERVIEWERS 1 and 2 , as shows TABLE 1 .

The results obtained with the application of the Brazilian THI in the second interview of INTERVIEWER 1 is found in TABLE 2.
Regarding the intraexaminer reproductibility evaluation, no significant statistical difference was found between the results obtained with the application of the Brazilian THI by INTERVIEWER 1 in the patients with tinnitus, as shows TABLE 2 .

CHART 2. Brazilian THI - Brazilian version of Tinnitus Handicap Inventory.

1. Devido ao seu zumbido é difícil se concentrar?

2. O volume (intensidade) do seu zumbido faz com que seja difícil escutar as pessoas?

3. O seu zumbido deixa você nervoso?

4. O seu zumbido deixa você confuso?

5. Devido ao seu zumbido, você se sente desesperado?

6. Você se queixa muito do seu zumbido?

7. Devido ao seu zumbido, você tem dificuldade para pegar no sono à noite?

8. Você sente como se não pudesse se livrar do seu zumbido?

9. O seu zumbido interfere na sua capacidade de aproveitar atividades sociais (tais como sair para jantar, ir ao cinema)?

10. Devido ao seu zumbido, você se sente frustrado?

11. Devido ao seu zumbido, você pensa que tem uma doença grave?

12. O seu zumbido torna difícil aproveitar a vida?

13. O seu zumbido interfere nas suas tarefas no serviço e em casa?

14. Devido ao seu zumbido, você se sente freqüentemente irritado?

15. Devido ao seu zumbido, você acha difícil ler?

16. O seu zumbido deixa você chateado?

17. Você sente que o seu zumbido atrapalha o seu relacionamento com a sua família e amigos?

18. Você acha difícil tirar a sua atenção do zumbido e se concentrar em outra coisa?

19. Você sente que não tem controle sobre o seu zumbido?

20. Devido ao seu zumbido, você se sente freqüentemente cansado?

21. Devido ao seu zumbido, você se sente freqüentemente deprimido?

22. O seu zumbido faz com que você sinta ansioso?

23. Você sente que não pode mais suportar o seu zumbido?

24. O seu zumbido piora quando você está estressado?

25. O seu zumbido faz com que você se sinta inseguro? 
TABLE 1. Average, median, standard deviation and p-value in relation to the scores of the catastrophic, functional and emotional aspects with the application of the Brazilian THI by INTERVIEWERS 1 and 2 for the interexaminer reproductibility evaluation.

\begin{tabular}{|c|c|c|c|c|c|c|c|c|}
\hline \multirow{2}{*}{$\begin{array}{l}\text { Entrevistadora } 1 \\
\text { Entrevistadora } 2\end{array}$} & \multicolumn{2}{|c|}{ Catastrófico } & \multicolumn{2}{|c|}{ Funcional } & \multicolumn{2}{|c|}{ Emocional } & \multicolumn{2}{|c|}{ Total } \\
\hline & $\begin{array}{l}\text { Primeiro } \\
\text { Entrevistador }\end{array}$ & $\begin{array}{c}\text { Segundo } \\
\text { Entrevistador }\end{array}$ & $\begin{array}{c}\text { Primeiro } \\
\text { Entrevistador }\end{array}$ & $\begin{array}{l}\text { Segundo } \\
\text { Entrevistador }\end{array}$ & \begin{tabular}{c|} 
Primeiro \\
Entrevistador
\end{tabular} & $\begin{array}{c}\text { Segundo } \\
\text { Entrevistador }\end{array}$ & $\begin{array}{c}\text { Primeiro } \\
\text { Entrevistador }\end{array}$ & $\begin{array}{l}\text { Segundo } \\
\text { Entrevistador }\end{array}$ \\
\hline Média & 10,47 & 8,53 & 17,80 & 17,67 & 17,40 & 17,00 & 45,67 & 43,20 \\
\hline Mediana & 10 & 9 & 16 & 15 & 17 & 14 & 40 & 35 \\
\hline desvio padrão & 5,27 & 6,41 & 12,30 & 12,70 & 9,46 & 10,37 & 25,10 & 27,35 \\
\hline $\mathrm{p}$-valor & \multicolumn{2}{|c|}{0,207} & \multicolumn{2}{|c|}{0,967} & \multicolumn{2}{|c|}{0,876} & \multicolumn{2}{|c|}{0,717} \\
\hline
\end{tabular}

TABLE 2. Average, median, standard deviation and p-value in relation to the scores of the catastrophic, functional and emotional aspects with the application of the Brazilian THI by INTERVIEWER 1 in the first and second interviews for the intraexaminer reproductibility evaluation.

\begin{tabular}{|c|c|c|c|c|c|c|c|c|}
\hline \multirow{2}{*}{ Entrevistadora 1} & \multicolumn{2}{|c|}{ Catastrófico } & \multicolumn{2}{|c|}{ Funcional } & \multicolumn{2}{|c|}{ Emocional } & \multicolumn{2}{|c|}{ Total } \\
\hline & $\begin{array}{l}\text { Primeiro } \\
\text { Entrevistador }\end{array}$ & $\begin{array}{l}\text { Segundo } \\
\text { Entrevistador }\end{array}$ & $\begin{array}{l}\text { Primeiro } \\
\text { Entrevistador }\end{array}$ & $\begin{array}{c}\text { Segundo } \\
\text { Entrevistador }\end{array}$ & $\begin{array}{l}\text { Primeiro } \\
\text { Entrevistador }\end{array}$ & $\begin{array}{l}\text { Segundo } \\
\text { Entrevistador }\end{array}$ & $\begin{array}{l}\text { Primeiro } \\
\text { Entrevistador }\end{array}$ & $\begin{array}{l}\text { Segundo } \\
\text { Entrevistador }\end{array}$ \\
\hline Média & 10,47 & 9,73 & 17,80 & 16,27 & 17,40 & 16,07 & 45,67 & 42,07 \\
\hline Mediana & 10 & 11 & 16 & 12 & 17 & 15 & 40 & 33 \\
\hline Desvio Padrão & 5,27 & 6,62 & 12,30 & 12,58 & 9,46 & 10,31 & 25,10 & 27,19 \\
\hline $\mathrm{p}$-valor & \multicolumn{2}{|c|}{0,637} & \multicolumn{2}{|c|}{0,635} & \multicolumn{2}{|c|}{0,604} & \multicolumn{2}{|c|}{0,596} \\
\hline
\end{tabular}

\section{Discussion}

The tinnitus is a very frequent symptom and due to its clinical characteristics it may cause important disorders in the social, professional and emotional activities damaging, this way, the QL of the patients. (Casaprima, 2001).

The conventional exams used for the clinical diagnosis of diseases accompanied by the tinnitus are insufficient to evaluate the impairments imposed by this symptom.

Therefore, offering a an instrument for the evaluation of the QL of patients with tinnitus is important for a better option of treatment and for the monitoring of these patients.

Some questionnaires have already been used for this purpose and also associated with the audiological aspects, psychological factors and general health. Among them, the Tinnitus Handicap Questionnaire (Kuk et al., 1990), Tinnitus Severity Questionnaire (Coles et al., 1991), Tinnitus Handicap Inventory (Newman et al., 1994), Tinnitus Handicap Inventory (Baguley e Norman, 2001) and TRQ (Meric et al., 1998). The THI was developed in English by Newman et al. (1996) and has already been translated and culturally adapted for its application in the Danish, Spanish and French populations (Zacharie et al., 2000; Herráiz et al., 2001; Bouscau-Faure et al., 2003).

In Brazil, some questionnaires are being used to evaluate the QL in several health areas, however it was not found in the scientific literature a questionnaire focusing on the damages caused by the tinnitus in the QL of Brazilian people. The cultural adaptation of the THI for the Brazilian Portuguese is of fundamental importance for its application, once there are cultural and social differences that may be present in the original version of THI that was addressed to the United States of America.

These differences are not solved with only one literal translation, being necessary to take into account the cultural adaptation process and the questionnaire application in order to determine the correspondence of metric characteristics between the original and the translated versions (Castro, 2003). 
Therefore, the translation and the cultural adaptation of the THI followed the stages proposed by Guillemin et al. (1993), internationally accepted and used in other studies, such as Roland-Morris Questionnaire (Natour et al., 2001), Patient Knowledge Questionnaire (Natour et al., 2002), Disability of the Arm, Shoulder and Hand (Dash) (Orfale, 2003), Dizziness Handicap Inventory (Castro, 2003) and Berg Balance Scale (Miyamoto et al., 2004).

In the cultural adaptation stage, only questions $1,10,24$ were unclear for $3 \%$ of the patients. The first doubt concerned the word "concentration" related to question number 1 ; the second doubt concerned the word "frustrated" found in question 10 ; and the last one concerned the word "stresses" found in question 24. The patients reported that those verbs thwarted the understanding, although all patients answered the respective questions, showing interest in expressing their idea about the term asked in the question. The number of patients was not relevant for the modification of the questions or for changing the words and /or expressions (Guillemin et al., 1993).

The reliability of the THI was also determined by Zacharie et al. (2000), Baguley andNorman (2001), Herráiz et al. (2001) and Bouscau-Faure et al. (2003) in the respective versions.

Concerning the emotional aspect, The Brazilian THI allows to evaluate the relation between the tinnitus and manifestations of stress, frustration, irritation, bothering, depression, anxiety, insecurity, and the difficulty in the relationship with family and friends, showed by the evaluated patients. According to Lynn et al. (2003), the tinnitus interferes in reading activities, in the sleep, cause anxiety and depression; the authors also suggested the use of the Symptom Checklist-90Revised as a complementary instrument for the evaluation of anguish severity, somatization and hostility generated by the tinnitus. As for the functional aspect, the Brazilian THI allows to identify the interference of the tinnitus with the activities involving concentration, hearing acuity, attention, sleep, with social and daily activities, reading, besides the tiring sensation that this symptom may provoke and the worsening of the tinnitus with the stress, as reported the evaluated patients.

The catastrophic aspect of the Brazilian THI allows the recognition of negative sensations produced by the tinnitus in the patients' lives, such as despair, intolerance to the tinnitus and loss of control of the situation.

Other studies also verified that the tinnitus may lead to deletery effects in the patients' lives (Coles et al., 1981; Nascimento, 1999; Baguley et al., 2000; Casaprima, 2001; Berry et al., 2002) observed that the application of THI during the tinnitus therapeutic process, named tinnitus training therapy may help in the improvement of selfperception of the patients, as well as to quantify this symptom in relation to the emotional, functional and catastrophic aspects.

The Brazilian THI may be used with the Brazilian population as a clinical evolution parameter and/ or as therapeutic monitoring of patients with tinnitus.

\section{Conclusions}

The THI was translated and culturally adapted for the Brazilian population, being called Brazilian THI.

The THI was considered a reliable instrument for the verification of the damages in the quality of life caused by the tinnitus.

The evaluated patients of this research presented damages in their QL as regards to the catastrophic, functional and emotional aspects due to the tinnitus. 


\section{References}

BAGULEY, D.; NORMAN M. Tinnitus handicap inventory. J. Am. Acad. Audiol., v. 12, n. 7, p. 379-380, jul.-aug. 2001 .

BAGULEY, D. M.; HUMPHRISS, R. L.; HONDGSON, C. A. Convergent validity of the tinnitus handicap inventory and the tinnitus questionnaire. J. Laryngol. Otol., v. 114, n. 11, p. 840-843, 2000.

BENDER, B. G. Measurement of quality of life in pediatrics asthma clinical trial. Ann. Allergy Asthma Immunol., v. 77, n. 6, p. 438-446, dec. 1996.

BENTO, R. F.; SANCHES, T. G.; MINITTI, A.; CÂMARA, J. Zumbido: características e epidemiologia. Rev. Bras. Otorrinolaringol., v. 63, n. 2, p. 229-238, 1997.

BERRY, J. A.; GOLD, S. L.; FREDERICK, E. A.; GRAY, W. C.; STAECKER, H. Patient-based outcomes in patients with primary tinnitus undergoing tinnitus retraining therapy. Arch. Otolaryngol. Head Neck Surg., v. 128, n. 10, p. 1153-1157, oct. 2002.

BOUSCAU-FAURE, F.; KELLER, P.; DAUMAN, R. Further validation of the iowa tinnitus handicap questionnaire. Acta Otolaryngol., v. 123, n. 2, p. 227-231, jan. 2003.

CASAPRIMA, V. Estudio descriptivo sobre las caracteristicas del acufeno en pacientes adultos que concurren a una clinica privada de ORL de la ciudad de Rosario. 2001. 101 f. Dissertação. (Mestrado na Área de Comunicacão: Fonoaudiologia) - Facultad de Ciencias Medicas - Escuela de Fonoaudiologia, Rosário.

CASTAGnO, L. A.; CASTAGNO, S. Tinnitus: a clinical study. Folha Méd., v. 91, n. 5/6, p. 393-395, 1985.

CASTRO, A. S. O. Dizziness handicap inventory: adaptação cultural para o português brasileiro, aplicação, reprodutibilidade e comparação com os resultados a vestibulometria. 2003. 59 f. Dissertação. ( Mestrado em Comunicação) - Universidade Bandeirante de São Paulo, São Paulo.

CICONELLI, R. M. Estudo clínico laboratorial e avaliação da qualidade de vida em pacientes que apresentam e não apresentam tontura. 1993. 123 f. Dissertação. (Mestrado em Medicina) - Universidade Federal de São Paulo, São Paulo.

COLES, R. R. A.; DAVID, A. C.; HAGGARD, M. P. Epidemiology of tinnitus. In: EVERED, D.; LAWRENSON, G., (Eds.). Tinnitus. London: Pitman Books, 1981. p. 1634. (Ciba Foundation Symposium, 85).

COLES, R. R. A.; LUTMAN, M. E.; AXELSSON, A.; HAZELL, J. W. P. Tinnitus severity gradings: cross sectional studies. In: ARAN, J. M.; DAUMAN, R., (Eds.). Tinnitus. New York: Kugler, 1991. p. 475-460.

FIELDER, H.; DENHOLM, S. W.; LYONS, R. A.; FIELDER, C. P. Measurement of health status in patients with vertigo. Clin. Otolaryngol., v. 21, n. 2, p. 124-126, apr. 1996.

FUKUDA, Y. Zumbido e suas correlações otoneurológicas. In: GANANÇA M. M. Vertigem tem cura? São Paulo: Lemos Editorial, 1998. p. 171-176.
FONSECA, J. S.; MARTINS, G. A. Curso de estatística. 6. ed. São Paulo: Editora Atlas, 1996. 320 p.

GUILLEMIN, F.; BOMBARDIER, C.; BEATON. D. Crosscultural adaptation of health-related quality of life measures: literature review and proposed guidelines. J. Clin. Epidemiol. v. 46, n. 12 , p. $1417-1432$, dec. 1993.

HERRÁIZ, C.; HERNÁNDEZ, C. J.; PLAZA, G.; TAPIA, M. G.; de LOS SANTOS, G. Disability evaluation in patients with tinnitus. Acta Otorrinolaringol. Esp., v. 52, n. 6, p. 534-538, aug.-sep. 2001.

KUK, F.; TYLER, R. S.; RUSSELL, D.; JORDAN, H. The psychometric properties of a tinnitus handicap questionnaire. Ear Hear., v. 11, n. 6, p. 434-445, dec. 1990.

LYNN, S. G.; BAUCH, C. D.; WILLIAMS, D. E.; BEATTY, C. W.; MELLON W.; WEAVER A. L. Psychologic profile of tinnitus patients using the SCL-90-R and tinnitus handicap inventory. Otol. Neurotol., v. 24, n. 6, p. 878881, nov. 2003

MERIC, C.; GARTHER, M.; COLLET, L.; CHÉRY-CROZE, S. Psychopathological profile of tinnitus sufferers: evidence concerning the relationship between tinnitus features and impact on life. Audiol. Neurootol., v. 3, n. 4, p. 253-264, jul.-aug. 1998.

MIYAMOTO, S. T.; LOMBARDI JÚNIOR, I.; BERG, K. O.; RAMOS, L. R.; NATOUR, J. Brazilian version of the Berg balance scale. Braz. J. Med. Biol. Res., v. 37, n. 9, p. 1411-1421, 2004.

MURRAY, R. S.; Estatística. 3. ed. São Paulo: Afiliada, 1993. 640 p. (Coleção Schaum).

NASCIMENTO, M. G. S. Adaptação e validação do questionário $R Q L Q$ para aplicação da qualidade de vida em crianças e adolescentes com rinite alérgica. 1999. Dissertação. 148 f. (Mestrado em Medicina) - Universidade Federal de São Paulo, São Paulo.

NATOUR, J.; NUSBAUM, L.; FERRAZ, M. B.; GOLDENBERG, J. Translation, adaptation and validation of the Roland-Morris questionnaire - Brazil Roland-Morris. Braz. J. Med. Biol. Res., v. 34, n. 2, p. 203-210, 2001.

NATOUR, J.; SIMÕES, M. F. J.; ASSIS, M. R.; TOFFOLO, S. Brasil "Patient Knowledge Questionnaire" (PKQ) e avaliação do conhecimento sobre a doença de pacientes com artrite reumatóide. Rev. Bras. Reumatol., v. 42, n. 1, p. 32-34, 2002.

NEWMAN, C. W.; JACOBSON, G. P.; SPITZER, J. B. The development of the Tinnitus Handicap Inventory. Arch. Otolaryngol. Head Neck Surg., v. 122, n. 2, p. 143-148, feb. 1996.

NEWMAN, C. W.; WHARTON, J. A.; SHIVAPUJA, B. G.; JACOBSON, G. P. Relationships among psychoacoustic judgements, speech understanding ability and self perceived handicap in tinnitus subject. Audiology, v. 33, n. 1, p. 4760, 1994. 
NORMAN, M.; BAGULEY, D. Tinnitus handicap inventory. J. Am. Acad. Audiol., v. 12, n. 7, p. 379-380, aug. 2001.

ORFALE, A. G.. Tradução e validação do disability of the arm, shoulder and hand (Dash), para a língua portuguesa. 2003. Dissertação. (Mestrado em Medicina) - Universidade Federal de São Paulo, São

Paulo.

ZACHARIAE, R.; MIRZ, F.; JOHANSEL, L. V.; ANDERSEN, S. E.; BJERRING, P.; PEDERSEN, C. B. Reliability and validity of a danish adaptation of the tinnitus handicap inventory. Scand. Audiol., v. 29, n. 1, p. 37-43, 2000. 